\title{
Swimming velocities in otariids
}

\author{
Paul J. Ponganis ${ }^{1}$ \\ Physiological Research Laboratory A-004, Scripps Institution of Oceanography, La Jolla. CA 92037, U.S.A. \\ Edward P. Ponganis \\ Micromonitors, 1348 Shasta Avenue, San Jose, CA 95126, U.S.A. \\ Katherine V. Ponganis and Gerald L. Kooyman \\ Physiological Research Laboratory A-004, Scripps Institution of Oceanography, La Jolla, CA 92037, U.S.A. \\ ROGER L. GENTRY \\ National Marine Fisheries Service, National Marine Mammal Laboratory, 7600 Sand Point Way N.E., \\ Building 4, Seattle, WA 98115, U.S.A. \\ AND \\ Fritz TRILLmich \\ Max-Planck-Institut für Verhaltensphysiologie, Abteilung Wickler, D-8131 Seewiesen, Federal Republic of Germany
}

Received May 30, 1989

Ponganis, P. J., Ponganis, E. P., Ponganis, K. V., Kooyman, G. L., Gentry, R. L., and Trillmich, F. 1990. Swimming velocities in otariids. Can. J. Zool. 68: 2105-2112.

Velocities during surface swimming and diving were measured with microptocessor recorders in four otariid species: northern fur seals (Callorhinus ursinus), Galapagos sea lions (Zalophus californianus wollebaeki). Galapagos fur seals (Arctocephalus galapagoensis), and Hooker's sea lions (Phocarctos hookeri). Mean surface swimming velocities ranged from 0.6 to $1.9 \mathrm{~m} / \mathrm{s}$. Transit distances to feeding sites $(1.2-90 \mathrm{~km})$ were calculated using these velocities. Dive velocities, recorded every $15 \mathrm{~s}$, ranged from 0.9 to $1.9 \mathrm{~m} / \mathrm{s}$. These velocities were consistent with calculated minimal cost of transport velocities in the smaller species. Using time partitioning, the metabolic cost of a northern fur seal foraging trip is estimated on the basis of recorded velocities and their calculated energy costs. This value is within $6 \%$ of that previously made with doubly labeled water techniques.

Ponganis, P. J., Ponganis, E. P., Ponganis, K. V., Kooyman, G. L., Gentry, R. L., et Trillmich, F. 1990. Swimming velocities in otariids. Can. J. Zool. $68: 2105-2112$.

Des microprocesseurs enregistreurs ont permis de mesurer la vitesse au cours de la nage en surface et au cours de la plongée chez quatre espèces d'Otariidae: l'Otarie à fourrure (Callorhinus ursinus), le Lion de mer des Galapagos (Zalophus californianus wollebaeki), l'Otarie des Galapagos (Arctocephalus galapagoensis) et le Lion de mer de Hooker (Phocarctos hookeri). La vitesse moyenne de la nage en surface allait de 0,6 à $1,9 \mathrm{~m} / \mathrm{s}$. Les distances parcourues pour atteindre les sites d'alimentation $(1,2-90 \mathrm{~km})$ ont été évaluées à partir de ces vitesses. Les vitesses de plongée. enregistrées toutes les $15 \mathrm{~s}$, se situaient entre 0,9 et $1,9 \mathrm{~m} / \mathrm{s}$. Ces vitesses correspondent aux valeurs évaluées en fonction d'un coût minimal de transport chez la plus petite espèce. En tenant compte de la répartition du temps, le coût métabolique encouru par une Otarie à fourrure à la recherche de sa nourriture a été évalué d'après les vitesses enregistrées et les coûts énergétiques correspondants. Cette valeur se situe à moins de $6 \%$ des résultats obtenus auparavant par les techniques qui utilisent de l'eau doublement marquée.

[Traduit par la revue]

\section{Introduction}

Work rate is an important determinant of oxygen consumption $\left(\dot{V}_{\mathrm{O}_{2}}\right)$, and, as such, swimming velocity plays a significant role in the metabolic rate during surface swimming and diving in pinnipeds. For otariids, although considerable data have been collected on foraging trips and on dive durations and profiles (Gentry and Kooyman 1986a), little is known about swimming velocity. Indeed, only the average metabolic rate of an entire foraging trip to sea for northern fur seals is known (Costa and Gentry 1986); the individual contributions of some components (surface swimming and diving) are not known.

The little we know about swim velocity and energetics in marine mammals is a result of exercise studies of California sea lions (Feldkamp 1987), grey seals (Fedak 1986), and harbor seals (Davis et al. 1985). In the sea lion study, $\dot{V O}_{2}$ was found to be an exponential function of velocity. From the data obtained In that study, it was also possible to calculate the minimum cost of transport (MCT) velocity. This value is of interest because of the question of whether mammals, when they dive, swim at this blocity to maximize the distance travelled under water, or Whether they use some other tactic while hunting. To under-

\footnotetext{
'Author to whom correspondence should be addressed.

ied in Canada / Imprimé au Canada
}

stand the strategy of foraging and oxygen conservation while diving, a detailed analysis of swim velocities is necessary. The purpose of this study was to determine the swim velocities of several species of otariids that varied in size. With these data and previously collected metabolic data from animals swimming under controlled conditions, the data are used to calculate transit distances to feeding areas, determine if animals swim at the MCT velocity, calculate $\mathrm{VO}_{2}$ during diving and surface swimming in the wild, and estimate the energetic costs of various activities during a foraging trip. All of the above are based on the assumption that flow conditions in the laboratory study are approximately the same as those in the field. This problem is discussed later in the report.

\section{Methods}

\section{Capture techniques}

Adult fermales that were making foraging trips to sea between pup suckling intervals on shore were captured at these sites and times: seven northern fur seals (Callorhinus ursinus), St. George Island, AK, July and August 1985; two Galapagos sea lions (Zalophus californianus wollebaeki), Fernandina Island, October 1985; six Galapagos fur seals (Arctocephalus galapagoensis), Fernandina Island, April 1986; and five Hooker's sea lions (Phocarctos hookeri), Enderby Island, New Zealand, January and February 1987. The Galapagos sea lions were 
TABLE 1. Velocity meter calibration

\begin{tabular}{|c|c|c|c|c|c|c|c|}
\hline \multirow{2}{*}{$\begin{array}{l}\text { Meter } \\
\text { position } \\
(\mathrm{cm})\end{array}$} & \multirow{2}{*}{$\begin{array}{l}\text { Spindle } \\
\text { girth } \\
\text { (cm) }\end{array}$} & \multirow[b]{2}{*}{ Slope } & \multirow{2}{*}{$\begin{array}{c}\gamma \\
\text { intercept }\end{array}$} & \multicolumn{2}{|c|}{ SE of: } & \multirow[b]{2}{*}{$R^{2}$} & \multirow[b]{2}{*}{$N$} \\
\hline & & & & $y$ & slope & & \\
\hline 17 & 70 & 0.024 & -0.013 & 0.21 & 0.000425 & 0.959 & 137 \\
\hline 37 & 82 & 0.029 & -0.154 & 0.12 & 0.000352 & 0.986 & \\
\hline 60 & 70 & 0.025 & -0.042 & 0.13 & 0.000349 & 0.985 & 85 \\
\hline 80 & 50 & 0.030 & 0.147 & 0.06 & 0.000276 & 0.996 & 138 \\
\hline Post & - & 0.029 & 0.017 & 0.03 & 0.000213 & 0.997 & 50 \\
\hline
\end{tabular}

Nore: Calibration equations for a single paddle whel velocity meter are described in this table. Data were collected when the meter was mounted in different positions on a streamlined spindle (specified by distance from front of spindle) or when mounted on a submerged metal post. The $37-\mathrm{cm}$ position was at maximum girth and approximated the placement of the meter on the study animals. The spindle weighed $32 \mathrm{~kg}$, had a fineness ratio of 3.8 , wats $108 \mathrm{~cm}$ long, and was neutrally buoyant. The "post" values were those calculated when the meter was attached to a submerged metal post. Velocities ranged from 0.4 to $3.6 \mathrm{~m} / \mathrm{s}$.

lightly sedated with ketamine (Trillmich and Wiesner 1979). All other captures utilized noose and hoop net techniques (Gentry and Holt 1982: Gentry and Kooyman 1986b).

Body weights were obtained at the time of capture on all animals except the two Galapagos sea lions. We estimated their weights as 90 and $110 \mathrm{~kg}$ based on length and girth measurements of $189 \times 108 \mathrm{~cm}$ and $206 \times 116 \mathrm{~cm}$, respectively. Animals were held on restraint boards (Gentry and Holt 1982) while microprocessors were attached using a harness (Gentry and Kooyman 1986b), except for Galapagos fur seals where marine epoxy was used. The recorders were attached on the dorsum of the body just caudal to the shoulders in all species

Instruments were recovered by cutting the harness loose while the animal slept, or by recapturing the animal and manually removing the instrument.

\section{Microprocessor instrumentation}

The microprocessors were designed by us and consisted of four major sections: control, memory, computer interfacing, and analog sensing (including Signet paddlewheel velocity meter and IC Sensor pressure transducer). Microprocessors were enclosed in time depth recorder (TDR) housings $(5.3 \mathrm{~cm}$ in diameter, $20 \mathrm{~cm}$ in length, $570 \mathrm{~g}$ ) (Gentry and Kooyman 1986b) in all studies except those on Galapagos fur seals and Hooker's sea lions. In these, the microprocessor was embedded in an epoxy cylinder measuring $3.3 \mathrm{~cm}$ in diameter, $23 \mathrm{~cm}$ in length, and weighing $225 \mathrm{~g}$. The paddlewheel was mounted in a Plexiglas tube and placed at the front of either housing.

Velocity meters were calibrated in a ring tank with a cart moving at known velocities $(0.4-3.6 \mathrm{~m} / \mathrm{s})$. The ring tank and cart have been described previously (Williams and Kooyman 1985). The meters were mounted on either a submerged metal rod or a neutrally buoyant streamlined Styrofoam spindle weighing $32 \mathrm{~kg}$, with a fineness ratio (length/maximum diameter) of 3.8. The calibration equations derived near the point of maximal girth or on the post are similar (Table 1) and approximate the meter position (caudal to shoulders) on the animal. Although the calibration equations varied with mounting position on the spindle (Table 1), use of the equation derived near maximal girth resulted in only a $0.25 \mathrm{~m} / \mathrm{s}$ error in the $0-2 \mathrm{~m} / \mathrm{s}$ range when the meters were placed $20 \mathrm{~cm}$ cranial or caudal to that position. Such positions would correspond to the neck or caudal trunk of an otariid. Consequently, we consider the meter to be accurate despite possible minor variations in attachment position just caudal to the shoulders of these animals.

Since the recorder is mounted on the back, the velocity meter exits the water when the animal surfaces or porpoises. Time out of water is brief, however, and has only a minor effect on the microprocessor. The velocity measured by a microprocessor attached to a porpoising, $35-\mathrm{kg}$ California sea lion trained to follow a cart travelling around a ring tank was about $15 \%$ lower than the known cart velocity (G. L. Kooyman, unpublished data).

Velocity regression equations were assumed to be linear beyond the $3.6 \mathrm{~m} / \mathrm{s}$ range for calculation of higher velocities. These, however, were few in number and should not significantly affect data analysis results.
The pressure transducers were calibrated with standard pressure stations both at Scripps and in the field. Calibration curves were constructed using linear regression analysis.

The microprocessor's sampling and storage rates were programmable, and different programs were used to store data for the different species. Regardless of the storage program, when the microprocessor was activated to sample velocity, it counted the pulsed output of the velocity meter for $4 \mathrm{~s}$ at $7.5-\mathrm{s}$ intervals. Then, according to the storage interval, it averaged the counts over that time period and stored that value in its memory. Thus, a velocity value that was stored every $15 \mathrm{~s}$ was the average of two counts, and a 5 -min value was the average of 40 counts.

\section{Microprocessor programs}

All microprocessors stored I-h time markers from time of activation to allow real time calculations. The microprocessor sampling and storage programs were triggered by a depth threshold. For diving velocities (swim velocities during dives), the microprocessor sampled the pressure transducer output, determined if the threshold depth was exceeded, and if so, then sampled and stored velocity data at programmed intervals until it determined that the depth was less than the threshold depth. For surface velocity records, the animal had to be above the threshold depth for the data to be stored.

Diving velocities were stored at 15 -s intervals when the northern fur seals and Hooker's sea lions were below 10-m depth. The threshold depth was $5 \mathrm{~m}$ in the Galapagos sea lion. Surface velocities were stored every $2 \mathrm{~min}$ in the Galapagos sea lion, and every $4 \mathrm{~min}$ in the northern fur seal and Hooker's sea lion. In addition, the northern fur seal units were programmed to record only dive data or only surface data because of memory constraints of the units.

The program for the Galapagos fur seal did not utilize a pressure transducer, but, rather, stored swimming velocity every $5 \mathrm{~min}$ continuously. However, this species has a consistent diel pattern of feeding bouts (Kooyman and Trillmich 1986a) so that velocities were correlated with activity by time of day. Since velocities were continuously recorded, we used only the data for the most intense diving period from 19:00-23:00 (45-50\% of all dives by TDR records, Kooyman and Trillmich 1986a) for estimates of diving velocities. Night velocities (18:00-06:00) represent both surface and dive velocities during foraging trips. Day velocities $(06: 00-18: 00)$ represent surface swimming during nonforaging activity $(<5 \%$ of dives occur in ? this time period, Kooyman and Trillmich 1986a). Zero velocities (i.e., when an animal was not moving or hauled out) were not included in the analysis.

\section{Results}

Dive and surface velocity data for all species are presented in Tables 2 and 3. Velocity histograms are in Figs. 1-4.

Four dive velocity records (fur seals 1-4) and three surface, velocity records (fur seals 5-7) were obtained from seven northern fur seals. The data for fur seals 1,5 , and 6 were partial records of each animal's trip to sea. Records from the 
TABLE 2. Mean ( \pm SD), median, mode, and maximum diving velocities of four otariid species

\begin{tabular}{|c|c|c|c|c|c|c|c|}
\hline \multirow[b]{2}{*}{$\begin{array}{c}\text { Animal } \\
\text { No. }\end{array}$} & \multirow{2}{*}{$\begin{array}{c}\text { Mass } \\
(\mathrm{kg})\end{array}$} & \multicolumn{4}{|c|}{ Diving velocity $(\mathrm{m} / \mathrm{s})$} & \multirow[b]{2}{*}{$N$} & \multirow[b]{2}{*}{$\begin{array}{l}\text { Total min } \\
\text { sampled }\end{array}$} \\
\hline & & Mean $\pm S D$ & Median & Mode & Maximum & & \\
\hline \multicolumn{8}{|c|}{ Northern fur seal } \\
\hline 1 & 50 & $1.1 \pm 0.46$ & 1.2 & 1.6 & 2.5 & 756 & 189 \\
\hline 2 & 37 & $1.4 \pm 0.38$ & 1.4 & 1.6 & 2.7 & 1842 & 460 \\
\hline 3 & 46 & $1.4 \pm 0.44$ & 1.4 & 1.6 & 3.0 & 2858 & 714 \\
\hline 4 & 37 & $1.7 \pm 0.36$ & 1.7 & 1.9 & 3.3 & 3383 & 845 \\
\hline \multicolumn{8}{|c|}{ Galapagos sea lion } \\
\hline 1 & 90 & $1.8 \pm 0.24$ & 1.8 & 1.8 & 2.4 & 561 & 140 \\
\hline 4 & 110 & $2.3 \pm 0.56$ & 2.2 & 2.2 & 5.3 & 867 & 217 \\
\hline \multicolumn{8}{|c|}{ Hooker's sea lion } \\
\hline 1 & 111 & $1.4 \pm 0.30$ & 1.4 & 1.4 & 4.8 & 2576 & 644 \\
\hline 2 & 135 & $1.6 \pm 0.38$ & 1.6 & 1.6 & 3.8 & 2923 & 730 \\
\hline 3 & 123 & $0.9 \pm 0.40$ & 1.1 & 1.2 & 2.6 & 3622 & 905 \\
\hline 4 & 105 & $1.4 \pm 0.42$ & 1.4 & 1.4 & 2.1 & 115 & 29 \\
\hline 5 & 137 & $1.5 \pm 0.34$ & 1.4 & 1.4 & 4.8 & 2085 & 521 \\
\hline \multicolumn{8}{|c|}{ Galapagos fur seal } \\
\hline 3 & 34 & $1.5 \pm 0.42$ & 1.4 & 1.4 & 2.6 & 425 & 2125 \\
\hline 4 & 27 & $1.1 \pm 0.37$ & 1.1 & 1.2 & 1.8 & 178 & 890 \\
\hline 7 & 37 & $1.5 \pm 0.44$ & 1.4 & 1.3 & 2.3 & 143 & 715 \\
\hline 9 & 34 & $1.9 \pm 0.50$ & 1.9 & 1.9 & 3.1 & 110 & 550 \\
\hline 11 & 31 & $1.5 \pm 0.39$ & 1.5 & 1.5 & 2.1 & 165 & 825 \\
\hline 12 & 30 & $1.4 \pm 0.31$ & 1.4 & 1.4 & 2.1 & 96 & 180 \\
\hline
\end{tabular}

TaBle 3. Surface velocities of two sea lion species

\begin{tabular}{|c|c|c|c|c|c|c|c|}
\hline \multirow{2}{*}{$\begin{array}{c}\text { Animal } \\
\text { No. }\end{array}$} & \multirow{2}{*}{$\begin{array}{l}\text { Weight } \\
(\mathrm{kg})\end{array}$} & \multicolumn{4}{|c|}{ Surface velocity $(\mathrm{m} / \mathrm{s})$} & \multirow[b]{2}{*}{$N$} & \multirow{2}{*}{$\begin{array}{l}\text { Total min } \\
\text { sampled }\end{array}$} \\
\hline & & Mean $\pm S D$ & Median & Mode & Maximum & & \\
\hline \multicolumn{8}{|c|}{ Galapagos sea lion } \\
\hline 1 & 90 & $1.3 \pm 0.35$ & 1.4 & 1.4 & 2.1 & 64 & 128 \\
\hline 4 & 110 & $1.6 \pm 0.64$ & 1.5 & 1.4 & 2.8 & 117 & 234 \\
\hline \multicolumn{8}{|c|}{ Hooker's sea lion } \\
\hline 1 & 111 & $1.5 \pm 0.49$ & 1.5 & 1.5 & 3.1 & 226 & 904 \\
\hline 2 & 135 & $1.2 \pm 0.44$ & 1.3 & 1.4 & 2.1 & 186 & 744 \\
\hline 3 & 123 & $1.0 \pm 0.44$ & 1.1 & 1.1 & 3.9 & 148 & 592 \\
\hline 4 & 105 & $1.3 \pm 0.52$ & 1.4 & 1.7 & 2.3 & 131 & 524 \\
\hline 5 & 137 & $1.2 \pm 0.69$ & 1.2 & 1.9 & 2.1 & 111 & 444 \\
\hline
\end{tabular}

other northern fur seals represented all the dive velocities or all the surface velocities from each trip to sea. Mean surface velocities were $0.8-1.0 \mathrm{~m} / \mathrm{s}$; dive data are given in Table 2 .

Both surface and dive velocities were recorded from the Galapagos and Hooker's sea lions. Hooker's sea lion 4 was a partial record.

Records from each of the six Galapagos fur seals studied include several overnight trips to sea. These recorders remained on the animals until they were relocated and recaptured after 3-14 days. Data by time of day were used, as discussed in Methods, to estimate surface and dive velocities. Analysis of night (18:00-06:00) swimming velocities, which includes both dive and surface velocities of foraging trips revealed means of $1.1-1.9 \mathrm{~m} / \mathrm{s}$. Mean surface velocities (06:00-18:00) were $0.6-1.4 \mathrm{~m} / \mathrm{s}$. Dive data are given in Table 2 .

In all species, mean surface velocity values ranged from 0.6 to $1.6 \mathrm{~m} / \mathrm{s}$; dive velocities varied from 0.9 to $1.9 \mathrm{~m} / \mathrm{s}$. The distributions of velocity data were not normal (Figs. 1-4). There was significant skewness in all the dive velocity distributions except Galapagos fur seal 7 and Hooker's sea lion 2 $(p<0.05)$ (Sokal and Rohlf 1981); significant kurtosis occurred in Galapagos fur seal 9 and in Hooker's seal lions 1 and $5(p<$ 0.05 ) (Sokal and Rohlf 1981). Among surface velocity distributions, significant kurtosis occurred only in Hooker's sea lion 3. 

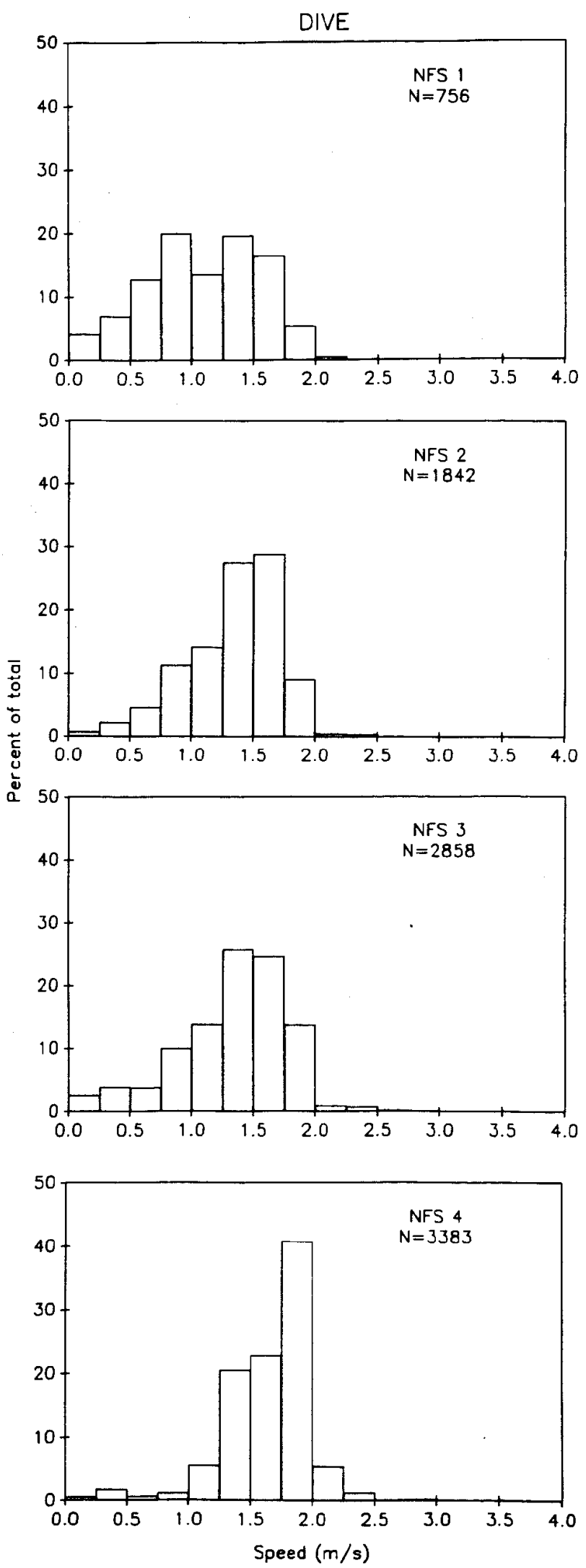

Fig. 1. Dive velocity histograms of northern fur seals (NFS 1-4).
TABLE 4. Estimated transit distances $(\mathrm{km})$ during foraging trips

\begin{tabular}{|c|c|c|c|}
\hline \multicolumn{2}{|l|}{ Anima } & \multirow[b]{2}{*}{ Outbound } & \multirow[b]{2}{*}{ Inbound } \\
\hline Species & No. & & \\
\hline \multirow[t]{2}{*}{ Northern fur seal ${ }^{a}$} & 6 & 90 & $\cdots$ \\
\hline & 7 & 84 & 82 \\
\hline \multirow[t]{2}{*}{ Galapagos sea lion } & 1 & 8.7 & 1.2 \\
\hline & 4 & 6.3 & 5.3 \\
\hline Galapagos fur seals ${ }^{\circ}$ & - & $10.5-18.1$ & $8.3-14.2$ \\
\hline
\end{tabular}

${ }^{a}$ Based on recorded surface velocities from departure until first dive bout. and from las dive bout until shore arrival.

${ }^{b}$ Calculated as in footnote $a$. However, both animals began scattered dives almost upon departure and continued scattered. shallow dives until within $4-10 \mathrm{~min}$ of arrival ashore. 'Distance calculated using transit times from TDR records (Trillmich and Kooyman 1986) and range of individual means of Galapagos fur seal night data.

Skewness was significant (some positive, some negative) in all except the Galapagos sea lions, Galapagos fur seals 3 and 9, and Hooker's sea lions.

Since the velocity distributions did not appear normal and variances were heterogeneous $(p<0.05)\left(F_{\max }\right.$-test, Sokal and Rohlf 1981), the Wilcoxon signed rank test was used to evaluate differences in surface versus diving velocities in Hooker's sea lions. Dive velocities were not significantly different from surface velocities in the Hooker's sea lion ( $z=0.6742, p=0.5$ ).

Nonparametric techniques were also used to evaluate the correlation of dive velocity to body weight for all individuals. The Kendall coefficiont of rank correlation (Sokal and Rohlf 1981) was not significant even at the 0.1 level $(\tau=0.0294, n=$ $17)$ for mean dive velocity and body weight. Analysis of modes gave similar results $(\tau=0.0588)$.

\section{Discussion}

Since Galapagos fur seals rest offshore during the day and northern fur seals rest during their foraging trips (Gentry et al. $1986 a$ ), the method of surface velocity measurement is biased by behavior. Owing to the potential for intermittent rest during the long sampling periods, the measurements do not reflect actual swimming velocity, and the data are not presented further. Such overall average velocities, however, are useful for transit distance and metabolic rate calculations. In contrast, Galapagos sea lions tend to continue swimming until a foraging trip is over (Kooyman and Trillmich 1986b). Time-depth recordings of 14 Hooker's sea lions also showed that they rested an average $2 \%$ of their total sea time (R. L. Gentry and W. Roberts, manuscript in preparation). Therefore, surface velocity data tend to reflect actual swimming speed. This is supported by the lack of significant difference between surface and diving velocities in the Hooker's sea lion.

Dive velocities, which were recorded every $15 \mathrm{~s}$, give a more detailed analysis of swimming speed. Furthermore. the 19:0023:00 data of the Galapagos fur seals are also considered to represent actual swimming velocities during dives for two reasons. First, very little time is spent at rest $(<3 \%)$ during the entire foraging trip in this species. Second, during dive bouts, these seals average 16 dives $/ h$, and 19:00-23:00 is the most intense diving period (Kooyman and Trillmich 1986a).

In evaluating the velocities recorded by this technique, one more factor must be considered. The recording device increases drag. Drag increased $1.65 \times$ when a $37-\mathrm{kg}$ California sea lion was fitted with a TDR and harness and towed at $2.0 \mathrm{~m} / \mathrm{s}$ (Feldkamp 1987). Higher velocities increased drag even more. 

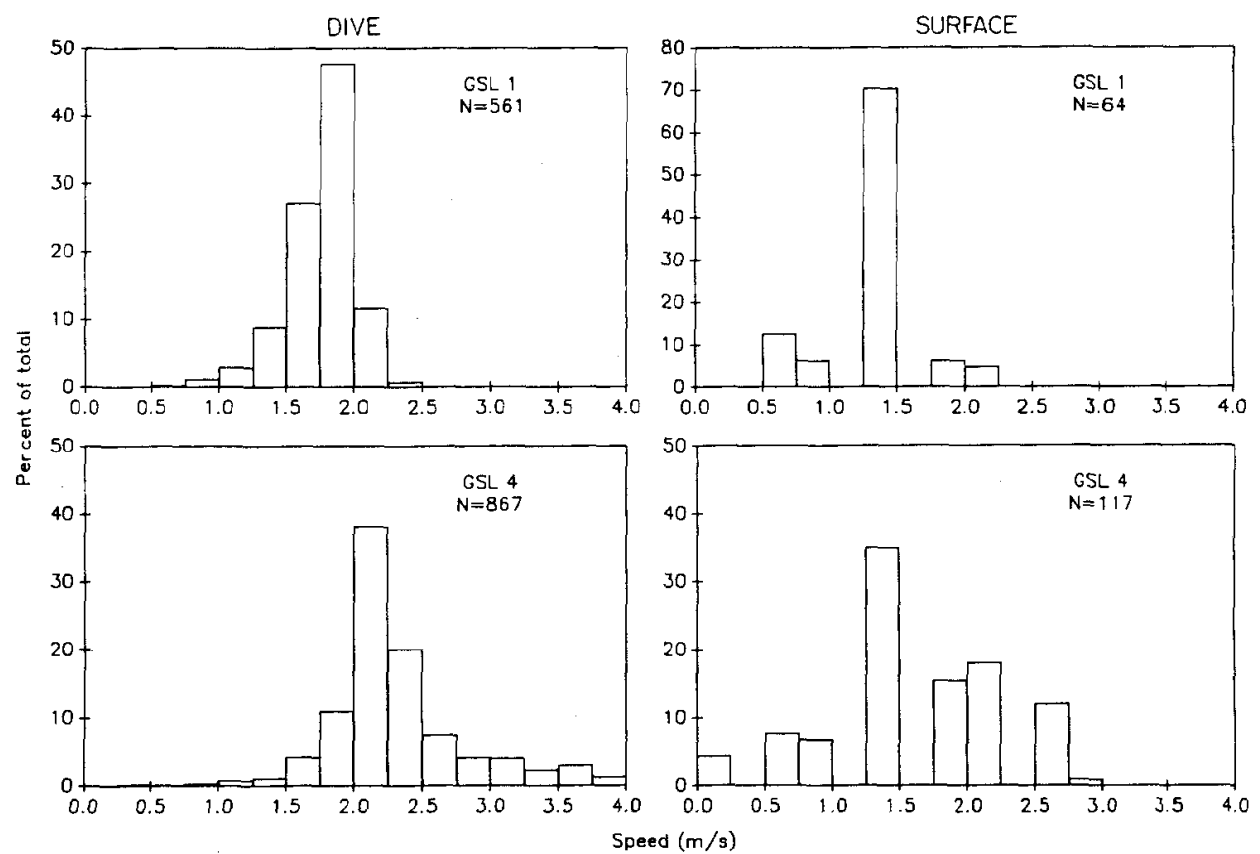

FIG. 2. Galapagos sea lion (GSL 1, 4) velocity histograms. Velocities greater than $4.0 \mathrm{~m} / \mathrm{s}$ are included in the last histogram interval. Dive sample rate is every $15 \mathrm{~s}$; surface rate is every $4 \mathrm{~min}$.

TABLE 5. Calculation of foraging trip metabolic rate for northern fur seals

\begin{tabular}{lccc}
\hline \multicolumn{1}{c}{ Activity } & $\begin{array}{c}\dot{\mathrm{VO}}_{2} \\
(\mathrm{~mL} \mathrm{O} /(\mathrm{kg} \cdot \min ))^{4}\end{array}$ & $\%$ time $^{b}$ & $\begin{array}{c}\text { Contribution to } \\
\text { total } \dot{V}_{2} \\
\left(\mathrm{~mL} \mathrm{O} \mathrm{O}_{2} /(\mathrm{kg} \cdot \min )\right)\end{array}$ \\
\hline Rest & 20.7 & 17 & 3.5 \\
Swim & 26.4 & 57 & 15.0 \\
Dive & 30.2 & 26 & 7.9 \\
Specific dynamic action ${ }^{c}$ & 2.6 & - & 2.6 \\
Total & & & 29.0 \\
\hline
\end{tabular}

${ }^{a} \dot{V}_{\mathrm{O}_{2}}=20.7 \mathrm{e}^{0.27 \mathrm{v}}$, where $V=$ velocity $(\mathrm{m} / \mathrm{s}) ;$ adapled from the formula of Feldkamp (1987) for Zalophus californianus $(18 \mathrm{~kg}), \mathrm{VO}_{2}=15.3 \mathrm{e}^{0.27 V}$, where 15.3 is the calculated resting metabolic rate in $19^{\circ} \mathrm{C}$ water and $20.7 \mathrm{~mL} \mathrm{O} 2 /(\mathrm{kg} \cdot \mathrm{min})$ is the calculated resting metabolic rate of a $40-\mathrm{kg}$ northern fur seal in $6^{\circ} \mathrm{C}$ water. This value is scaled according to $M^{0.75}$ from the mean resting metabolic rate of $24.6 \mathrm{~mL} \mathrm{O} /(\mathrm{kg} \cdot \mathrm{min})$ for six northern fur seals (weights, 17-23 kg) in $6^{\circ} \mathrm{C}$ water (R. W. Davis and G. L. Kooyman unpublished data). Calculations used a surface velocity of $0.9 \mathrm{~m} / \mathrm{s}$ and diving velocity of $1.4 \mathrm{~m} / \mathrm{s}$.

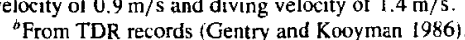

'From TDR records (Gentry and Kooyman 1986). on resting metabolic rate in marine mammals (Costa and Kooyman 1984).

Overall, foraging trip metabolic rate increases by $19 \%$ in northern fur seals equipped with TDRs (Costa and Gentry 1986). The effect of increased drag on the velocities recorded in the wild is unknown and must be remembered in interpretation of the results. However, we have noted in underwater observations of emperor penguins, a diver of approximately the same mass as the smaller fur seals, that when the birds swam as a group, the one equipped with the recorder kept up with the rest of the group but made fewer dives. We suspect the same may be true of mammals as well when and if they swim together. Except for in shore observations where we have seen fur seals departing and arriving together, we have no observations on this behaviour.

Table 4 gives estimated transit distances for the three species for which average transit times are known (Gentry et al. 1986b). The Galapagos fur seal distances are based on mean TDR transit time estimates (based on departures and arrivals ashore before and after the first and last dives) and the range of individual mean night velocities. The distances of the other two species are based on the actual surface velocities recorded during transits until the first dive bout or after the last dive bout. Both species from the Galapagos swim short distances to the feeding areas; these distances are trivial compared with the $80-$ to $90-\mathrm{km}$ swim of the northern fur seal during its approximately 1 week long sojourn at sea.

In contrast to transit distances calculated for northern fur seals from St. George Island, Loughlin et al. (1987) have radiotracked fur seals from St. Paul Island to feeding sites 160 $200 \mathrm{~km}$ away. The transit times for these fur seals averaged $48 \mathrm{~h}$, considerably longer than the 15 recorded for St. George fur 

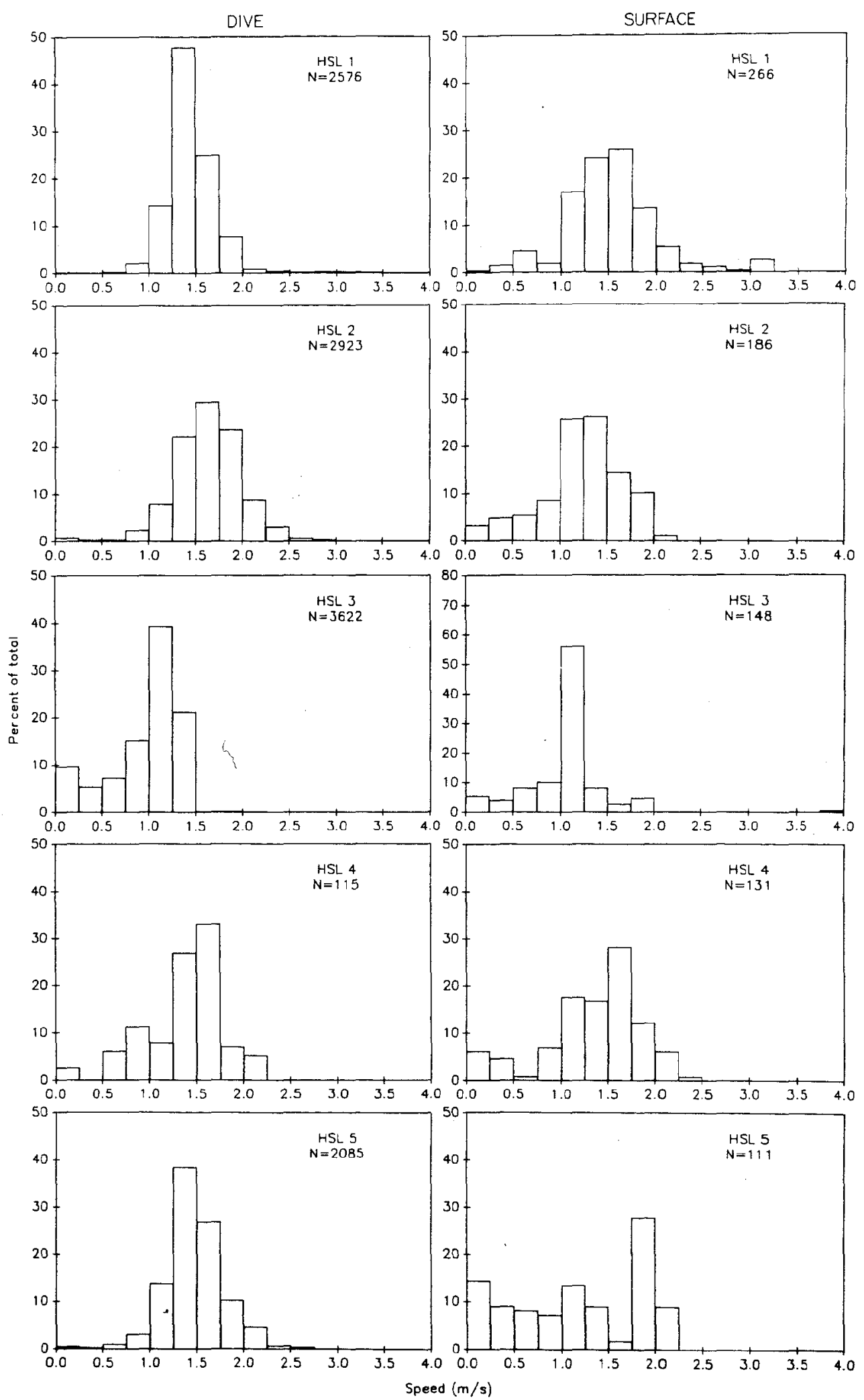

FIG. 3. Velocity histograms of Hooker's sea lions (HSL 1-5). Velocities greater than $4.0 \mathrm{~m} / \mathrm{s}$ are included in the last histogram interval. D sample rate is every $15 \mathrm{~s}$; surface every $4 \mathrm{~min}$. 

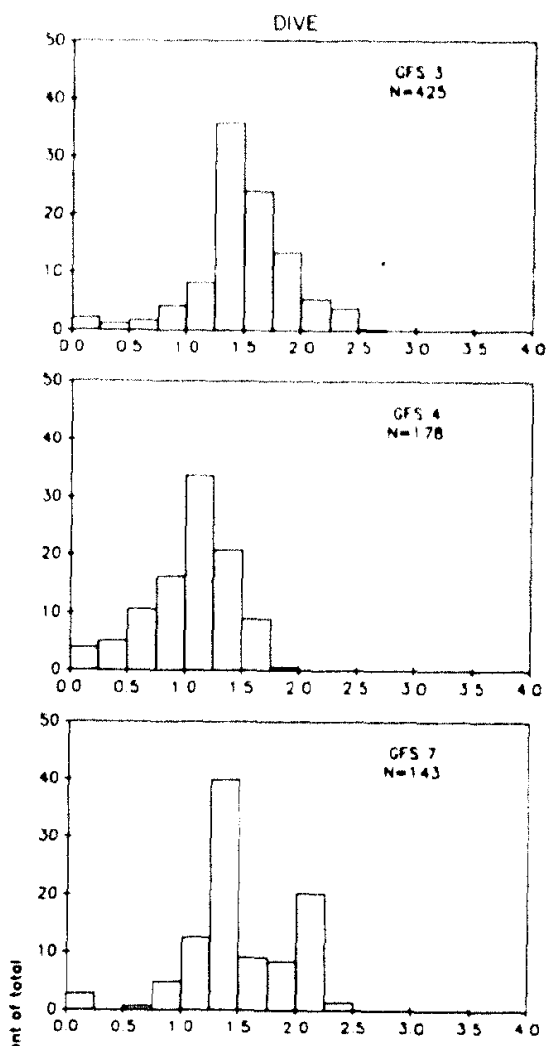

:
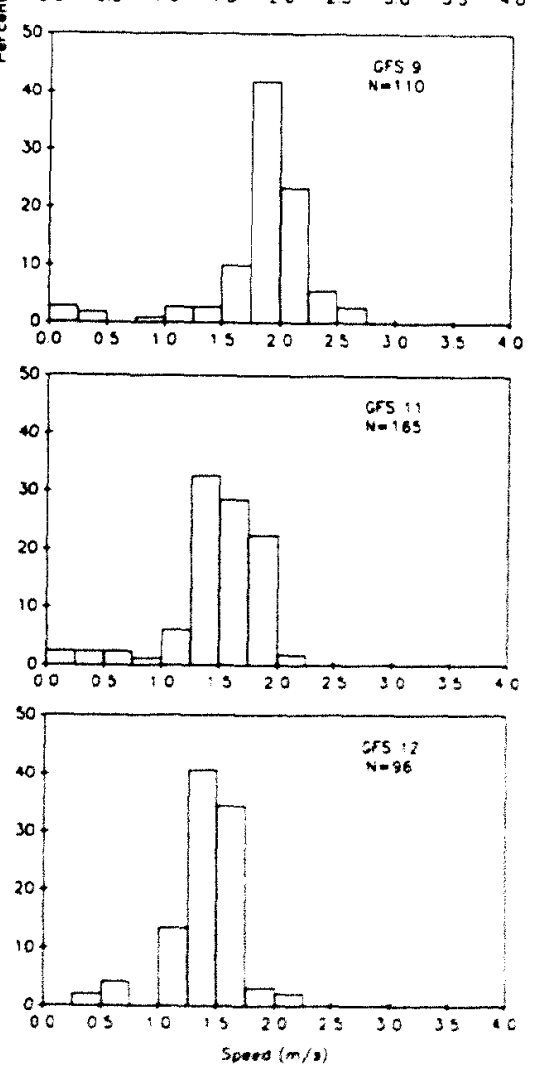

G. 4. Galapagos fur seal (GFS 3, 4, 7, 9, 11, 12) dive velocity grams. seals. Loughlin et al. (1987) postulated that transit distances may be less for $S t$. George fur seals. and our data support this hypothesis.

Otariid dive velocities have not been reported prior to this study. Descent and ascent (D/A) rates calculated from TDR records during deep dives of adult fernale California sea lions (Feldkamp 1985) and norhern fur seals (Centry et al. 1986) give a range from $0.7-1.5 \mathrm{~m} / \mathrm{s}$ in sea lions and $0.98-1.7 \mathrm{~m} / \mathrm{s}$ in the fur seals. The sea lion D/A rates are lower than swim speeds, as expected, if the D/A angles are nor $9\left(0^{\circ}\right.$. The D/A values of the fur seal are equal to the dive velocities, suggesting the $D / A$ angles of the fur seal are nearly $90^{\circ}$.

With the exception of the Hooker's sea lion data, the observed mean dive velocities are probably equal to or less than the MCT velocity (Feldkamp 1987). For these otariids, the mean diving velocity is probably near the most economical velocity in terms of distance covered and consumption of available oxygen stores. This may maximize their ability to hunt underwater by permitting the greatest distance to be covered with the available oxygen store and still remain within the animal's aerobic dive limit. This is discussed in detail by Gentry et al. $(1986 b)$.

Exercise studies of Feldkamp (1987) also allow one to calculate $\mathrm{VO}_{2}$ based on swimming speed. Restrictions on the interpretation of such calculations include the species studied. the water temperature, and the size and age of the animals. The average water temperature near the Pribilof lslands is $5^{\circ} \mathrm{C}$. Mean resting metabolic rate of six immature (still growing) northern fur seals in $6^{\circ} \mathrm{C}$ water in a metabolic chamber was $24.6 \mathrm{~mL} \mathrm{O} /(\mathrm{kg} \cdot \mathrm{min})(\mathrm{R}$. W. Davis and G. L. Kooyman, unpublished data; weights: $17-23 \mathrm{~kg}$ ). The northern fur seals in that study were approximately half the mass of those in this study. We scaled this value to $20.7 \mathrm{~mL} \mathrm{O} /(\mathrm{kg} \cdot \mathrm{min})$ for a 40-kg fur seal according to standard metabolic rate scale (i.e.. body weight $\left.{ }^{(0.75}\right)$, and used that value as resting $\dot{V}_{2}$ in Feldkamp's exponential equation (Feldkamp 1987). The metabolic rates of swimming, resting. and diving are calculated in Table 5. The average metabolic rate of an entire trip was calculated to be $29.0 \mathrm{~mL} \mathrm{O} /(\mathrm{kg} \cdot \mathrm{min})$. This value is 6.5 times the predicted resting Kleiber metabolic rate for a $40-\mathrm{kg}$ animal (4.5 $\mathrm{mL} \mathrm{O}_{2} /(\mathrm{kg} \cdot \mathrm{min})$; Kleiber 1975$)$.

As stated previously. Costa and Gentry (1986) determined the foraging trip metabolic rate in northern fur seals by isotopic methods. Their rate for an instrumented fur seal was $9.87 \mathrm{~W} / \mathrm{kg}$ or $30.8 \mathrm{~mL} \mathrm{O}_{2} /(\mathrm{kg} \cdot \mathrm{min})$ (assuming fat oxidation), again approximately 7 times the predicted resting Kleiber rate. This is encouraging because it indicates that an energy budget can be calculated by time partitioning after discrete measurement of metabolic values for various activities. The advantages of time partitioning over isotope estimates are that (i) it can be measured more cheaply, even in very large animals. (ii) it can be analyzed in the field, and (iii) it also allows large sample sizes to be obtained.

In conclusion, swim velocities in four otarid species have been measured with microprocessor recorders. Mean dive velocities do not correlate with body size. Dive velocities in the smaller species are consistent with predicted MCT velocities. The larger animals dive at slower than predicted velocities. indicating the need for exercise studies of larger otariids, as well as further microprocessor-based studies of diving behaviour. Calculations of foraging energetics based on laboratory-derived resting and swimming metabolic rates, and time partitioning of 
the animal's activities while at sea, appear to give good estimates.

\section{Acknowledgements}

We thank Phil Thorson, Don Croll, Tory Kooyman, Thomas Dellinger, Wendy Roberts, Martin Cawthorn, Robert Warneke, Chris Thomas, and Joe Slovacek for assistance in the field or laboratory, and Evelyn Conley for graphs. We also thank the Serviceo Parque Nacional Galapagos and its Independentes Ings. F. Cepeda and H. Ochoa for the permit to work in Galapagos, and them and the Estacion Cientifica Charles Darwin through its Director, Dr. G. Reck, for their constant support. This project was supported by National Marine Fisheries Service contract MM-85-95, National Geographic grant 3144-85, and National Science Foundation grant DCB 84-07291. We gratefully acknowledge the support of Fritz Trillmich through W. Wickler by the Max-Planck Gesellschaft, and by the Deutsche Forschungsgemeinschaft, grant TR 105/4.

Costa, D. P., and Gentry, R. L. 1986. Free-ranging energetics of northern fur seals. In Fur seals: maternal strategies on land and at sea. Edited by R. L. Gentry and G. L. Kooyman. Princeton University Press, Princeton, NJ. pp. 79-101.

CostA, D. P., and Kooyman, G. L. 1984. Contribution of specific dynamic action to heat balance and thermoregulation of the sea otter Enyhydra lutris. Physiol. Zool. 57: 199-203.

Davis, R. W., Williams, T. M., and Kooyman, G. L. 1985. Swimming metabolism of yearling and adult harbor seals, Phoca vitulina. Physiol. Zool. 58: 590-596.

FEDAK, M. A. 1986. Diving and exercise in seals: a benthic perspective. In Diving in animals and men. Kongsvold Symposium, Norwegian Society of Sciences and Letters, June 3-7, 1985 , Kongsvold, Norway. Edited by A. Brubakk, J. W. Kanwisher, and G. Sundnes. Tapir Publishers, Trondheim. pp. 11-32.

FeldKamp, S. D. 1987. Swimming in the California sea lion morphometrics, drag, and energetics. J. Exp. Biol. 131: 117-135.

GeNTRY, R. L., and HoLT, J. R. 1982. Equipment and techniques for handling northern fur seals. U.S. Department of Commerce, NOAA Tech. Rep. NMFS SSRF-758.

Gentry, R. L., and Kooyman, G. L. (Editors). 1986a. Fur seals: maternal strategies on land and at sea. Princeton University Press, Princeton, NJ.

Gentry, R. L., and Kooyman, G. L. 1986b. Methods of dive analysis. In Fur seals: maternal strategies on land and at sea. Edited by R. L. Gentry and G. L. Kooyman. Princeton University Press, Princeton, NJ. pp. 28-40.

Gentry, R. L., Kooyman, G. L., and Goebel, M. E. $1986 a$. Feeding and diving behavior of northern fur seals. In Fur seals: maternal strategies on land and at sea. Edited by R. L. Gentry and G. L. Kooyman. Princeton University Press, Princeton, NJ. pp. 61-78.

Gentry, R. L., Costa, D. P., Croxall, J. P., David, J. H. M., Davis, R. W., Kooyman, G. L., Majluf, P., McCann, T. S., and TRILLMICH, F. 1986b. Synthesis and conclusions. In Fur seals: maternal strategies on land and at sea. Edited by R. L. Gentry and G. L. Kooyman. Princeton University Press, Princeton, NJ. pp. 220-264.

KLeIber, M. 1975. The fire of life. Robert Krieger, New York.

Kooyman, G. L., and TriLlmich, F. 1986a. Diving behavior of Galapagos fur seals. In Fur seals: maternal strategies on land and at sea. Edited by R. L. Gentry and G. L. Kooyman. Princeton University Press, Princeton, NJ. pp. 186-195.

1986 b. Diving behavior of Galapagos sea lions. In Fur seals: maternal strategies on land and at sea. Edited by R. L. Gentry and G. L. Kooyman. Princeton University Press, Princeton, NJ. pp. 209-219.

Loughlin, T. R., Bengston, J. L., and Merrick, R. L. 1987. Characteristics of feeding trips of female northern fur seals. Can. J. Zool. 65: 2079-2084.

SoKal, R. R., and RoHLF, F. J. 1981. Biometry. W.H. Freeman and Co., San Francisco.

Trillmich, F., and Wiesner, H. 1979. Immobilization of freeranging Galapagos sea lions. Vet. Rec. 105: 465-466.

Williams, T. M., and Kooyman, G. L. 1985. Swimming performance and hydrodynamic characteristics of harbor seals, Phoca vitulina. Physiol. Zool. 58: 576-589. 